\title{
Complexes of Thallium(I) and Cadmium(II) with Dipeptides of L-phenylalanylglycine and Glycyl-L-phenylalanine
}

\author{
Sasan Sharifi, ${ }^{a}$ Davood Nori-shargh ${ }^{a, b}$ and Azar Bahadory ${ }^{*, a}$ \\ ${ }^{a}$ Chemistry Department, Islamic Azad University, Arak Branch, Arak, Iran \\ ${ }^{b}$ Chemistry Department, Islamic Azad University, Science and Research Branch, Tehran, Hesarak, Iran
}

\begin{abstract}
As constantes de estabilidade dos complexos de íons tálio(I) e cádmio(II) com dipeptídeos de glicil-L-fenilalanina e L-fenilalanilglicina foram determinadas em solução aquosa a $25{ }^{\circ} \mathrm{C}$ e meio iônico $0,1 \mathrm{~mol} \mathrm{dm}^{-3}$ usando uma combinação de técnicas potenciométricas e espectrofotométricas. Perclorato de sódio foi usado para manter a força iônica. A composição dos complexos formados foi determinada e observou-se que tálio(I) e cádmio(II) formam duas espécies mononucleares 1:1 com os ligantes, do tipo $[\mathrm{Tl}(\mathrm{HL})]^{+}, \mathrm{TlL},[\mathrm{Cd}(\mathrm{HL})]^{2+}$ e $[\mathrm{CdL}]^{+}$no intervalo do $\mathrm{pH}$ de estudo (1,5-10,5), onde L representa um ligante completamente dissociado. Os logaritmos das contantes de estabilidade cumulativas, $\beta_{\mathrm{xyz}}$, dos complexos, [(íon metálico) $\left(\mathrm{H}^{+}\right)_{\mathrm{y}}(\text { ligante) })_{\mathrm{z}}$, são $\log \beta_{111}$ e $\log \beta_{101}: 12,15$ e 3,39 (para $\mathrm{Tl}^{+}$com L-fenilalanilglicina), 11,36 e 2,13 (para $\mathrm{Tl}^{+}$com glicil-L-fenilalanina), 12,06 e 2,82 (para $\mathrm{Cd}^{2+}$ com L-fenilalanilglicina) e 10,70 e 1,70 (para $\mathrm{Cd}^{2+}$ com glicil-L-fenilalanina), respectivamente.
\end{abstract}

The stability constants of the complexes of thallium(I) and cadmium(II) ions with dipeptides of glycyl-L-phenylalanine and L-phenylalanylglycine were determined in aqueous solution at $25^{\circ} \mathrm{C}$ and $0.1 \mathrm{~mol} \mathrm{dm}^{-3}$ ionic medium using a combination of potentiometric and spectrophotometric techniques. Sodium perchlorate was used to maintain the ionic strength. The composition of the formed complexes was determined and it was shown that thallium(I) and cadmium(II) forms two mononuclear 1:1 species with the ligands, of the type [Tl(HL) $]^{+}$, $\mathrm{TlL},[\mathrm{Cd}(\mathrm{HL})]^{2+}$ and $[\mathrm{CdL}]^{+}$in the $\mathrm{pH}$ range of study $(1.5-10.5)$, where $\mathrm{L}$ represents a fully dissociated ligand. The logarithms of the cumulative stability constants, $\beta_{\mathrm{xyz}}$, of the complexes, $\left[(\text { Metal ion })_{\mathrm{x}}\left(\mathrm{H}^{+}\right)_{\mathrm{y}}(\text { ligand })_{\mathrm{z}}\right]$, are $\log \beta_{111}$ and $\log \beta_{101}: 12.15,3.39$ (for $\mathrm{Tl}^{+}$with $\mathrm{L}$ phenylalanylglycine), 11.36, 2.13 (for $\mathrm{Tl}^{+}$with glycyl-L-phenylalanine), 12.06, 2.82 (for $\mathrm{Cd}^{2+}$ with L-phenylalanylglycine), 10.70 and 1.70 (for $\mathrm{Cd}^{2+}$ with glycyl-L-phenylalanine), respectively.

Keywords: L-phenylalanylglycine, glycyl-L-phenylalanine, cadmium(II) complexes, thallium(I) complexes

\section{Introduction}

The recent increased use of peptides in biomedical therapy is a result of their large range of activity and specificity, usually with low toxicity and rapid metabolization. For the near future, an increasing activity in design and synthesis of new peptide-based drugs is expected, as a result of combined advances in proteomic research and biotechnology. Thus, separation, analysis of peptides and peptide hormones and determination of stability constants of metal complexes with peptides has become increasingly important for an ever-widening range of research disciplines. ${ }^{1}$

*e-mail: s.sharifi@royalpearlchem.com, a.bahadory@yahoo.com
On the other hand, research results have clearly demonstrated that certain transition metal ions play a basic role in directing a number of biochemical processes. ${ }^{2}$ Many biological processes involve hydrolysis of proteins and peptides. Metal ions can promote the hydrolysis of peptides and related compounds in both homogeneous and heterogeneous systems. Hydrolysis of proteins and peptides has been studied more from a biochemical than from chemical point of view, and since certain proteolytic enzymes require metal ions for activity, hydrolysis reactions and complexes of peptides with metal ions have attracted the attention of chemists. ${ }^{3}$

The increasing rate of the environment pollution has stimulated worldwide research concerning new materials capable to remove heavy metal of cadmium(II) from 
contaminated soils and wastes. ${ }^{4}$ Also, thallium has been recognized as a toxic element for many years. It produces a variety of adverse effects in human being. This element acts on the central nervous system and induces inflammatory response. However, the metabolic mechanism and fate of thallium toxicity is still not well understood. Since thallium(I) shows marked similarities to that of potassium cation, its interaction with nucleotides, the monomeric units of DNA and RNA, in aqueous would be of a major biochemical interest. ${ }^{5}$

This revealed the need for comprehensive studies of metal ion-bioligand interactions, as model systems; within this, the investigation of the complex-forming properties of amino acids and peptides is of particular importance. ${ }^{2}$ The first studies were on metal complexes of polyglycines, the behaviour of the peptide group and, in particular, its acid dissociation being the most interesting problem at that stage. ${ }^{6}$

Transition metal complexes of amino acids and peptides in aqueous solution were studied by various techniques. ${ }^{6-20}$ Potentiometry and UV-Vis spectrophotometry are the most widely used methods in the investigation of metal-peptide complexes. ${ }^{6}$ Many analytical methods use molecular absorption spectrophotometry of coordination compounds for the determination of metal ions in solution. Consequently, the spectroscopic parameter of molar absorptivity $(\varepsilon)$ is of great importance in the practice of a chemical laboratory. Obviously, the interest is focalized on the research of coordination compounds that result in spectrophotometric measurements of great sensitivity, and therefore, high $\varepsilon_{\max }$ values. The spectroscopic parameters of molecular absorption $\lambda_{\text {max }}$ (wavelength at absorption maximum) and $\varepsilon_{\text {max }}$ (molar absorptivity at absorption maximum) are largely used in chemistry. There are generally three scopes for which the measurement of the absorption spectrum of a substance occurs: the qualitative recognition, the structural examination (these two objectives are in reality connected) and the quantitative determination. It is important to keep in mind, particularly when the study is performed in solution, that the spectra do not only depend on structural conditions of the measurant, but also on the environmental elements (nature of the solvent, $\mathrm{pH}$ value of the aqueous solutions, etc.), which make the acquired spectroscopic data to assume a conditional character. Many analytical methods base themselves on the molecular absorption spectrophotometry of coordination compounds for the determination of metal ions in solution; generally, it deals with relatively fast and economic methods, suitable for routine measurements on known matrixes, for which their sensitivity is linked to the $\varepsilon_{\text {max }}$ of the compound that is made to form in view of the spectrophotometric measurement. ${ }^{21}$
Therefore has been decided to carry out an equilibrium study of the interaction of peptides with metal ions to determine stability of species formed. These complexes may serve to determine the interactions leading to metal promoted hydrolysis. Also, the knowledge of the distribution of species with $\mathrm{pH}$ is a prerequisite for future kinetic studies. ${ }^{3}$

This work deals with the study of $\mathrm{Tl}(\mathrm{I})$ and $\mathrm{Cd}(\mathrm{II})$ complexes by L-phenylalanylglycine and glycyl-Lphenylalanine, and determining their stability constants at $25{ }^{\circ} \mathrm{C}$ and constant ionic strength $0.1 \mathrm{~mol} \mathrm{dm}^{-3}$ sodium perchlorate. The formation constants of the formed complexes have been compared with similar systems and interpreted.

\section{Experimental}

\section{Chemicals}

Glycyl-L-phenylalanine was obtained from Merck, while the L-phenylalanylglycine was provided by Fluka (purity $\geq 99 \%$ ). Both of the ligands were employed without further purification and the aqueous stock solutions of the ligands were freshly prepared daily. The $\mathrm{NaOH}$ solution was prepared from a titrisol solution (Merck) and its concentration was determined by several titrations with standard $\mathrm{HCl}$. Perchloric acid, sodium perchlorate, cadmium(II) nitrate and thallium(I) nitrate were from Merck as analytical reagent grade materials and were used without further purification. Dilute perchloric acid solutions were standardized against standard $\mathrm{NaOH}$ solution. All the standard solutions were prepared using deionized and twicedistilled water with specific conductance equal to $(1.8 \pm 0.1)$

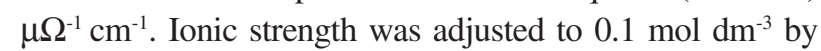
addition of $\mathrm{NaClO}_{4}$.

\section{Apparatus}

An Horiba pH-meter, M-12 was used for $\mathrm{pH}$ measurements. The hydrogen ion concentration was measured with an Ingold UO 3234 glass electrode and Ingold UO 3236 calomel electrod. Spectrophotometric titrations were performed on a UV-Vis PerkinElmer, Lambada 25 double beam spectrophotometer from 200 to $350 \mathrm{~nm}$ and optical path $1.000 \mathrm{~cm}$.

\section{Measurements}

All measurements were carried out at a constant temperature $(25.0 \pm 0.1){ }^{\circ} \mathrm{C}$ and ionic strength $0.1 \mathrm{~mol}$ $\mathrm{dm}^{-3}$ with sodium perchlorate. The $\mathrm{pH}$-meter was 
calibrated for the relevant $\mathrm{H}^{+}$concentration with solution of $0.01 \mathrm{~mol} \mathrm{dm}^{-3}$ perchloric acid solution containing 0.09 mol dm${ }^{-3}$ sodium perchlorate (for adjusting the ionic strength to $0.1 \mathrm{~mol} \mathrm{dm}^{-3}$ ). For this standard solution, we set $-\log \left[\mathrm{H}^{+}\right]=2.0 .{ }^{22}$ Junction potential corrections have been calculated from equation 1

$-\log \left[\mathrm{H}^{+}\right]_{\text {real }}=-\log \left[\mathrm{H}^{+}\right]_{\text {measured }}+\mathrm{a}+\mathrm{b}\left[\mathrm{H}^{+}\right]_{\text {measured }}$

$\mathrm{a}$ and $\mathrm{b}$ were determined by measuring hydrogen ion concentration for two different solutions of $\mathrm{HClO}_{4}$ with sufficient $\mathrm{NaClO}_{4}$ to adjust the ionic medium.

\section{Procedure}

Volumes of $25 \mathrm{~cm}^{3}$ acidic solution of $\mathrm{Tl}^{+}$and $\mathrm{Cd}^{2+}$ in the concentrations range $5 \times 10^{-6}$ to $5 \times 10^{-5} \mathrm{~mol} \mathrm{dm}^{-3}$ (respectively) were titrated with an alkali solution of each ligand containing a large excess of each ligand (the ratios of metal ion to ligand 1:100). Ionic strength was maintain at $0.1 \mathrm{~mol} \mathrm{dm}^{-3}$, in the presence of $\mathrm{NaClO}_{4}$. The $-\log \left[\mathrm{H}^{+}\right]$ and absorbance were measured after addition of a few drops of titrant, and this procedure extended up to required $-\log \left[\mathrm{H}^{+}\right]$. A purified nitrogen atmosphere was maintained in the vessel during the titrations. In all cases, the procedure was repeated at least three times. The resulting average values and corresponding standard deviation are shown in the Tables 1 and 2 .

\section{Results and Discussion}

The complex $\mathrm{M}_{\mathrm{x}} \mathrm{H}_{\mathrm{y}} \mathrm{L}_{z}^{(\mathrm{nx}+\mathrm{y}-\mathrm{z})+}$ formed is characterized by its stoichiometry (x:y:z), where $\mathrm{M}$ and $\mathrm{L}$ represent the metal ion and each ligand, respectively. To determine the stability constant of the complexation or the protonation, equation 2 is defined by $\beta_{\text {xyz }}{ }^{22}$

$$
\begin{aligned}
& \mathrm{xM}^{\mathrm{n+}}+\mathrm{yH}^{+}+\mathrm{zL}^{-} \rightleftharpoons \mathrm{M}_{\mathrm{x}} \mathrm{H}_{\mathrm{y}} \mathrm{L}_{\mathrm{z}}^{(\mathrm{nx}+\mathrm{y}-\mathrm{z})+} \\
& \beta_{\mathrm{xyz}}=\left[\mathrm{M}_{\mathrm{x}} \mathrm{H}_{\mathrm{y}} \mathrm{L}_{\mathrm{z}}^{(\mathrm{nx}+\mathrm{y}-\mathrm{z})+}\right] /\left(\left[\mathrm{M}^{+\mathrm{n}}\right]^{\mathrm{x}}\left[\mathrm{H}^{+}\right]^{\mathrm{y}}[\mathrm{L}]^{\mathrm{z}}\right)
\end{aligned}
$$

The protonation constants of the ligands have been used for computation of the stability constant, $\beta_{\mathrm{xyz}}$, of the metal-ligand. The protonation constants of the ligands have been extensively studied in different kinds of background electrolytes, and the results were reported in the literature. To illustrate, there are L-phenylalanylglycine and glycyl-L-phenylalanin dipeptides in solution to three species: molecular, cationic and anionic. ${ }^{23}$ For these dipeptides, we have two stages of the equilibriums

$$
\begin{aligned}
& \mathrm{H}_{2} \mathrm{~L}^{+}(\mathrm{aq})+\mathrm{H}_{2} \mathrm{O}(\mathrm{l}) \Longleftrightarrow \mathrm{H}_{3} \mathrm{O}^{+}(\mathrm{aq})+\mathrm{HL}(\mathrm{aq}) \quad \mathrm{K}_{\mathrm{a} 1}=\frac{\left[\mathrm{H}_{3} \mathrm{O}^{+}\right][\mathrm{HL}]}{\left[\mathrm{H}_{2} \mathrm{~L}^{+}\right]} \\
& \mathrm{HL}(\mathrm{aq})+\mathrm{H}_{2} \mathrm{O}(\mathrm{l}) \Longleftrightarrow \mathrm{H}_{3} \mathrm{O}^{+}(\mathrm{aq})+\mathrm{L} \text { (aq) } \mathrm{K}_{\mathrm{a} 2}=\frac{\left[\mathrm{H}_{3} \mathrm{O}^{+}\right]\left[\mathrm{L}^{-}\right]}{[\mathrm{HL}]}
\end{aligned}
$$

where $\mathrm{K}_{\mathrm{a} 1}$ and $\mathrm{K}_{\mathrm{a} 2}$ are stepwise dissociation constants. By used of equations 4 and 5 are obtained Henderson equations. Henderson's equations shows that, $\mathrm{pH}$ is a linear function to of $\log \frac{[\mathrm{HL}]}{\left[\mathrm{H}_{2} \mathrm{~L}^{+}\right]}$and $\log \frac{\left[\mathrm{L}^{-}\right]}{[\mathrm{HL}]}$ in acidic and basic titrations, respectively. From the intercept of these equations, the values of $\mathrm{pK}_{\mathrm{a} 1}$ and $\mathrm{pK}_{\mathrm{a} 2}$ can be obtained, respectively. In this work, the protonation constants of the ligands have been determined using potentiometric techniques and calculated using a computer program which employs a least-squares method. ${ }^{22}$

These values are listed in Table 1 together with the values reported in the literature, which are in good agreement with those reported in the literature and curves are given in Figures 1 and 2. The method of determination of the stability constant is based on the relation $\mathrm{A}=\mathrm{f}(\mathrm{pH})$ on account of the high stability of the complexes studied. Asborbance, $\mathrm{A}$, and $-\log \left[\mathrm{H}^{+}\right]$, were measured for a solution containing $\mathrm{Tl}^{+}, \mathrm{Cd}^{2+}$ with a large excess of each ligand. Treatments of the spectrophotometric data (each $1 \mathrm{~nm}$ )

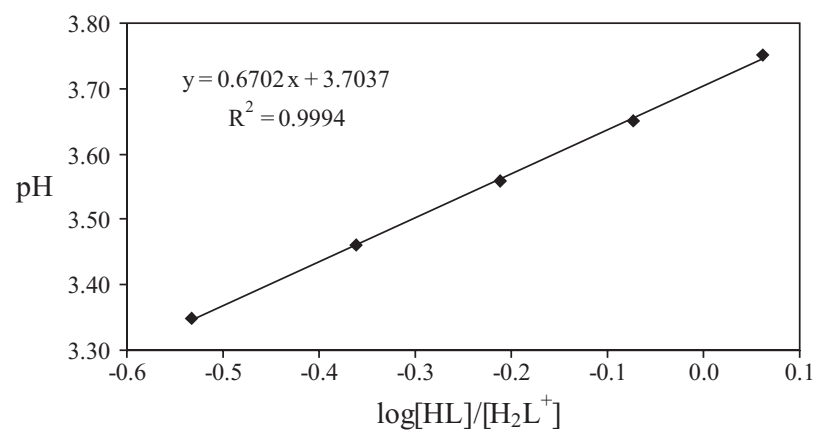

Figure 1. Curve $\mathrm{pH}$ vs. $\log [\mathrm{HL}] /\left[\mathrm{H}_{2} \mathrm{~L}^{+}\right]$for L-phenylalanylglycine.

Table 1. Protonation constants of glycyl-L-phenylalanine and L-phenylalanylglycine at $25^{\circ} \mathrm{C}$ and ionic strengths, $\mathrm{I}, 0.1 \mathrm{~mol} \mathrm{dm}^{-3}\left(\mathrm{NaClO}_{4}\right)$

\begin{tabular}{lllll}
\hline Species & $\log \beta_{011}$ & $\log \beta_{021}$ & Experimental Conditions & Ref. \\
\hline L-phenylalanylglycine & $3.7037 \pm 0.0029$ & $7.5236 \pm 0.0032$ & $\mathrm{NaClO}_{4}, \mathrm{I}=0.1 \mathrm{~mol} \mathrm{dm}^{-3} \mathrm{t}=25^{\circ} \mathrm{C}$ & This work \\
glycyl-L-phenylalanine & $3.2314 \pm 0.0020$ & $8.1106 \pm 0.0047$ & $\mathrm{NaClO}_{4}, \mathrm{I}=0.1 \mathrm{~mol} \mathrm{dm}^{-3} \mathrm{t}=25^{\circ} \mathrm{C}$ & $\mathrm{This}$ work \\
glycyl-L-phenylalanine & $3.11 \pm 0.14$ & $8.14 \pm 0.17$ & $\mathrm{NaClO}_{4}, \mathrm{I}=0.1 \mathrm{~mol} \mathrm{dm}^{-3} \mathrm{t}=25^{\circ} \mathrm{C}$ & 24 \\
\hline
\end{tabular}




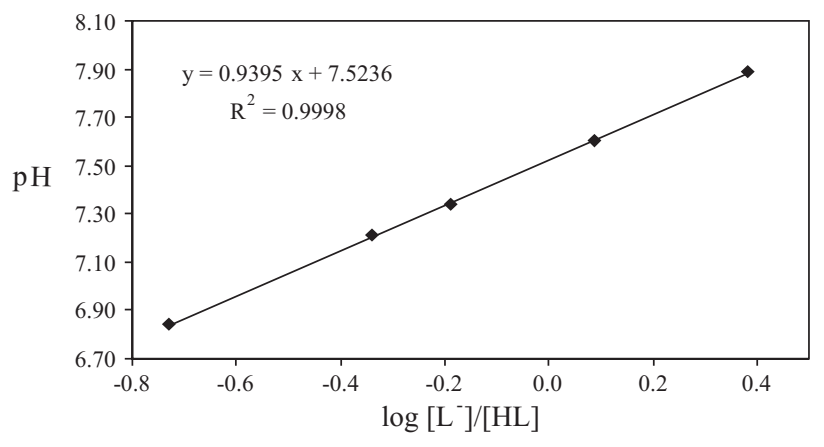

Figure 2. Curve $\mathrm{pH} v s . \log \left[\mathrm{L}^{-}\right] /[\mathrm{HL}]$ for L-phenylalanylglycine.

obtained during the titrations as a function of the $\mathrm{H}^{+}$ concentration were conducted on the computer program. The program allows calculation of stability constant for different models of stoichiometries. The degree of refinement then guides to the choice between models.

Considering the protonation constants of the ligands, in acidic $\mathrm{pH}$ the predominant species for complexation is $\mathrm{H}_{2} \mathrm{~L}^{+}$ for glycyl-L-phenylalanine and L-phenylalanylglycine. In this case the spectrophotometric titration data were analysed by using the absorbance of $\mathrm{Tl}^{+}$with each ligand at wavelengths in UV range that is given by

$\mathrm{A}=\varepsilon_{\mathrm{Tl}}\left[\mathrm{Tl}^{+}\right]+\varepsilon_{\mathrm{C}}\left[\mathrm{TlHL}^{+}\right]+\varepsilon_{\mathrm{H}_{2} \mathrm{~L}^{+}}\left[\mathrm{H}_{2} \mathrm{~L}^{+}\right]+\varepsilon_{\mathrm{HL}}[\mathrm{HL}]$

where $\varepsilon_{\mathrm{T} 1}$ and $\varepsilon_{\mathrm{C}}$ are the molar absorptivities of $\mathrm{Tl}^{+}$and each ligand, respectively. For the mass balance

$\mathrm{F}_{\mathrm{Tl}}=\left[\mathrm{Tl}^{+}\right]+\left[\mathrm{TlHL}^{+}\right]$

and if $\alpha_{1}$ and $\alpha_{0}$ be the fractions of the total concentration $\mathrm{HL}$ in the $\mathrm{H}_{2} \mathrm{~L}^{+}$and $\mathrm{HL}$, respectively

$\alpha_{1}=\frac{\left[\mathrm{H}_{2} \mathrm{~L}^{+}\right]}{\mathrm{F}_{\mathrm{HL}}}, \alpha_{0}=\frac{[\mathrm{HL}]}{\mathrm{F}_{\mathrm{HL}}}$

where $\mathrm{F}_{\mathrm{Tl}}$ and $\mathrm{F}_{\mathrm{HL}}$ are the total concentrations of $\mathrm{Tl}$ and each ligand, respectively. Substituting equations 3 and 7-9 into equation 6 gives the final equation for fitting. The method of determining $\varepsilon_{\mathrm{Tl}^{+}}$was previously described ${ }^{25}$ and its values at different wavelengths are used in this work. Using a suitable computer program ${ }^{22}$ the data were fitted to the final equation for estimating the formation constant of equation 3 . We used the Gauss-Newton nonlinear least-squares method in computer program to refine the absorbance by minimizing the error squares sum from equation 8

$$
U=\sum\left(a_{i}-b_{i}\right)^{2} \quad(\mathrm{i}=1,2,3, \ldots)
$$

where $a_{\mathrm{i}}$ is a quasi-experimental and $b_{\mathrm{i}}$ is a calculated one. The computer program consisted of two different kind of fitting, (A) graphical, (B) numerical. The final selection of the species was based on both graphical and numerical methods, considering in addition the various statistical criteria, i.e. sums of squared residuals, differences of $\mathrm{F}_{\mathrm{Tl}}$ (exp) and $\mathrm{F}_{\mathrm{HL}}$ (exp) from those of calculated one. Figure 3 is shown as an example of graphical fitting for the observed and calculated absorbances (from the computer program, by fitting method) of Tl(I)-L-phenylalanylglycine system against $-\log \left[\mathrm{H}^{+}\right]$.

Different models including ML, MHL and several polynuclear and protonated species were tested by the program. As expected, polynuclear complexes were systematically rejected by the computer program, as also were $\mathrm{MH}_{2} \mathrm{~L}, \mathrm{MHL}_{2}, \mathrm{ML}_{2}$ and $\mathrm{MH}_{2} \mathrm{~L}_{2}$. Values for some species were calculated by the program, but the species were not further considered because the estimated error in their formation constants are unacceptable, and their inclusion do not improve the goodness of the fit.

The models finally chosen, formed by $\mathrm{Tl}(\mathrm{HL})^{+}$and $\mathrm{TlL}$, for L-phenylalanylglycine and glycyl-L-phenylalanine, resulted in a satisfactory numerical and graphical fitting. The average values for various wavelengths calculated for the stability constants are listed in Table 2 .

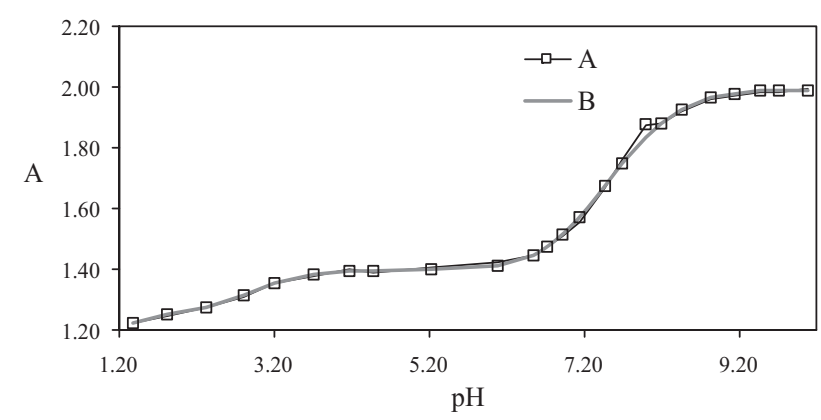

Figure 3. A typical graphical fitting Tl(I)-L-phenylalanylglycine system at $25{ }^{\circ} \mathrm{C}, 220 \mathrm{~nm}$, and ionic strength $0.1 \mathrm{~mol} \mathrm{dm}^{-3}\left(\mathrm{NaClO}_{4}\right)$, (A) experimental absorbance, (B) calculated absorbance from the computer program by fitting method.

Table 2. Average values of $\log \mathrm{b}_{111}$ and $\log \mathrm{b}_{101}$ for different wavelengths at $25^{\circ} \mathrm{C}$ and ionic strengths, $\mathrm{I}, 0.1 \mathrm{~mol} \mathrm{dm}^{-3}\left(\mathrm{NaClO}_{4}\right)$

\begin{tabular}{lllll}
\hline Species & $\log \beta_{111}$ & $\log \beta_{101}$ & Experimental Conditions & Ref. \\
\hline Tl(I)-L-phenylalanylglycine & $12.15 \pm 0.20$ & $3.39 \pm 0.20$ & $\mathrm{NaClO}_{4}, \mathrm{I}=0.1 \mathrm{~mol} \mathrm{dm}^{-3}, \mathrm{t}=25^{\circ} \mathrm{C}$ & This work \\
Tl(I)-glycyl-L-phenylalanine & $11.36 \pm 0.11$ & $2.13 \pm 0.06$ & $\mathrm{NaClO}_{4}, \mathrm{I}=0.1 \mathrm{~mol} \mathrm{dm}^{-3}, \mathrm{t}=25^{\circ} \mathrm{C}$ & This work \\
Cd(II)-L-phenylalanylglycine & $12.06 \pm 0.13$ & $2.82 \pm 0.08$ & $\mathrm{NaClO}_{4}, \mathrm{I}=0.1 \mathrm{~mol} \mathrm{dm}^{-3}, \mathrm{t}=25^{\circ} \mathrm{C}$ & This work \\
Cd(II)-glycyl-L-phenylalanine & $10.70 \pm 0.04$ & $1.70 \pm 0.07$ & $\mathrm{NaClO}_{4}, \mathrm{I}=0.1 \mathrm{~mol} \mathrm{dm}^{-3}, \mathrm{t}=25^{\circ} \mathrm{C}$ & This work \\
\hline
\end{tabular}


Benzyl-containing ligands, L-phenylalanylglycine and glycyl-L-phenylalanine, studied in this work may coordinate thallium(I) via the $-\mathrm{COO}^{-}$and $-\mathrm{NH}_{2}$ donor groups. In the case of Tl(I)-L-phenylalanylglycine system, the computer program suggests that the species MHL is possibly the only one present. This assumption was confirmed by offering some other species, as mentioned before, that all were rejected by the computer program. In Figures 4 and 5 the equilibrium distribution of various species in $\mathrm{Tl}(\mathrm{I})-\mathrm{L}-$ phenylalanylglycine and glycyl-Lphenylalanine systems are shown as a function of $-\log \left[\mathrm{H}^{+}\right]$, respectively. The calculations are based on the stability constant values given in Table 2 . In the $\mathrm{Tl}(\mathrm{I})-\mathrm{L}$ phenylalanylglycine and glycyl-L-phenylalanine systems, Figures 4 and 5, TlL is the dominant species in the $-\log \left[\mathrm{H}^{+}\right] \geq 10$, while $\mathrm{TlHL}^{+}$, is formed in the $-\log \left[\mathrm{H}^{+}\right]$ range 2.4-8.7 with a maximum near $-\log \left[\mathrm{H}^{+}\right], 5.4$, always accounts for less than $5 \%$ of the total metal ion concentration.

Considering Table 2, complexes formed by $\mathrm{Tl}(\mathrm{I})$ L-phenylalanylglycine are much more stable than those formed by glycyl-L-phenylalanine, and its $\log \beta_{111}$ is higher than those of glycyl-L-phenylalanine by about $1.1 \log$ units. There is a benzyl group in the ligands, the complexation of thallium(I) by the ligands indicates influence benzyl group on the donor sites $-\mathrm{COO}^{-}$and $-\mathrm{NH}_{2}$ in L-phenylalanylglycine and glycyl-L-phenylalanine for complex formation, i.e. $-\mathrm{COO}^{-}$in the

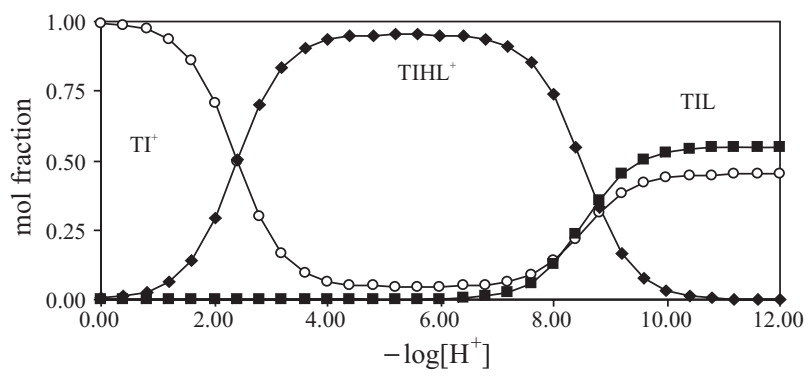

Figure 4. The equilibrium distribution of the species in $\mathrm{Tl}(\mathrm{I})-\mathrm{L}$ phenylalanylglycine system as a function of $-\log \left[\mathrm{H}^{+}\right]$at $25^{\circ} \mathrm{C}$ and ionic strength $0.1 \mathrm{~mol} \mathrm{dm}^{-3}$ sodium perchlorate.

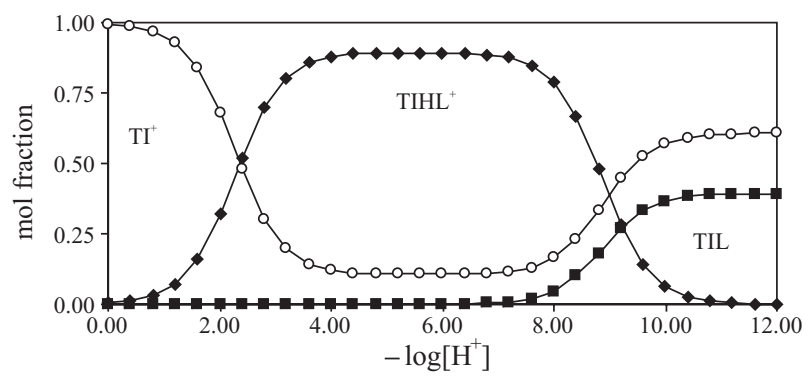

Figure 5. The equilibrium distribution of the species in Tl(I)-glycyl-Lphenylalanine system as a function of $-\log \left[\mathrm{H}^{+}\right]$at $25^{\circ} \mathrm{C}$ and ionic strength $0.1 \mathrm{~mol} \mathrm{dm}^{-3}$ sodium perchlorate.
L-phenylalanylglycine preference of thallium(I) for the $-\mathrm{COO}^{-}$donor group in the glycyl-L-phenylalanine because benzyl group decreases Lewis basicity and nucleophilicity donor sites.

The similar results were obtained for $\mathrm{Cd}(\mathrm{II})-\mathrm{L}-$ phenylalanylglycine and glycyl-L-phenylalanine systems, Figures 6 and 7, by potentiometric studies. Also, in this report we showed that the complexes formed by Tl(I)-Lphenylalanylglycine and glycyl-L-phenylalanine systems are much more stable than those formed by Cd(II)-Lphenylalanylglycine and glycyl-L-phenylalanine, and this could be due to thallium(I) have much more standard reduction potential and effective nuclear charge than cadmium(II), so we should expect a higher stability constant value for complex formation with thallium(I).

In this work, the study of thallium(I) and cadmium(II) with dipeptides of L-phenylalanylglycine and glycyl-Lphenylalanine interaction was attempted in order to better understand the influence of the presence of a benzyl group in the stability of dipeptides to bind thallium(I) and cadmium(II), also influence type of metal for complex formation.

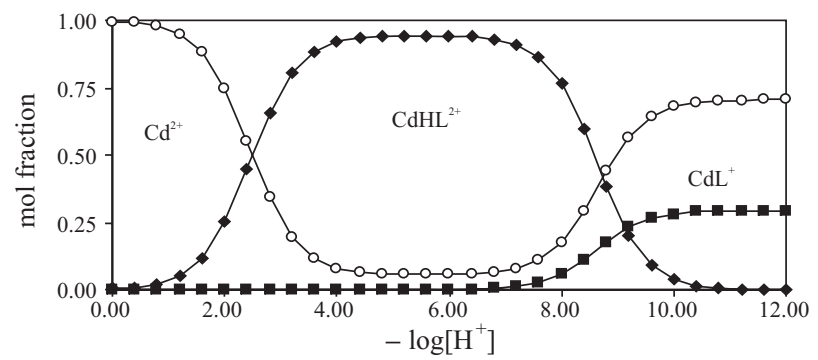

Figure 6. The equilibrium distribution of the species in $\mathrm{Cd}(\mathrm{II})-\mathrm{L}-$ phenylalanylglycine system as a function of $-\log \left[\mathrm{H}^{+}\right]$at $25^{\circ} \mathrm{C}$ and ionic strength $0.1 \mathrm{~mol} \mathrm{dm}^{-3}$ sodium perchlorate.

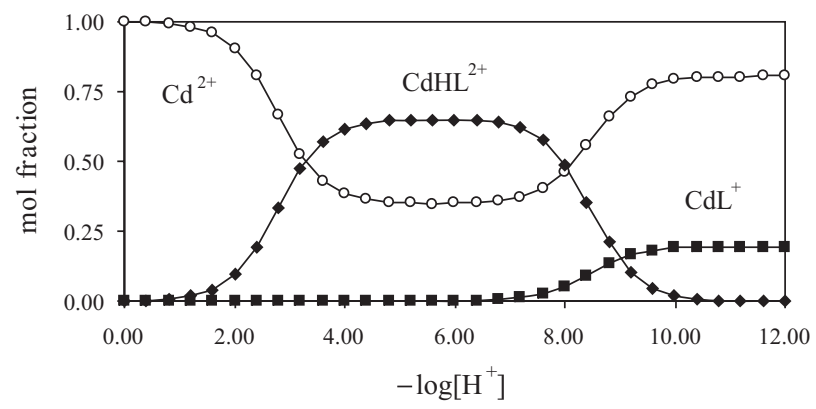

Figure 7. The equilibrium distribution of the species in Cd(II)-glycyl-Lphenylalanine system as a function of $-\log \left[\mathrm{H}^{+}\right]$at $25^{\circ} \mathrm{C}$ and ionic strength $0.1 \mathrm{~mol} \mathrm{dm}^{-3}$ sodium perchlorate.

These assumptions have been confirmed by the finding that the stability constant values of MHL and ML species formed by L-phenylalanylglycine are much higher than the corresponding values of glycyl-L-phenylalanine and the stability constant values thallium(I) complexes with 
both of ligands are much higher than the corresponding values for cadmium(II) complexes.

\section{Acknowledgments}

Thanks are gratefully extended to the Chemistry Department of Islamic Azad University, Arak Branch, for its invaluable help to this work.

\section{References}

1. Sanz-Nebot, V.; Benavente, F.; Toro, I.; Barbosa, J.; J. Chromatogr., A 2001, 921, 69.

2. Sóvágó, I.; Petocz, G.; J. Chem. Soc. Dalton Trans. 1987, 7, 1717.

3. Bordignon Luiz, M. T.; Szpoganicz, B.; Rizzoto, M.; Martell, A. E.; Basallote, M. G.; Inorg. Chim. Acta 1997, 254, 345.

4. Mavropoulos, E.; da Rocha, N. C. C.; Moreira, J. C.; Bertolino, L. C.; Rossi, A. M.; J. Braz. Chem. Soc. 2005, 16, 62.

5. Gharib, F.; Monajjemi, M.; Ketabi, S.; Main Group Met. Chem. 2004, 27, 71.

6. Daniele, P. G.; Zerbinati, O.; Aruga, R.; Ostacoli, G.; J. Chem. Soc. Dalton Trans. 1988, 5, 1115.

7. Nair, M. S.; Santappa, M.; Natarajan, P.; J. Chem. Soc. Dalton Trans. 1980, 11, 2138.

8. Lau, S.; Sarkar, B.; J. Chem. Soc. Dalton Trans. 1981, 2, 491.

9. Farkas, E.; Sóvágó, I.; Kiss, T.; Gergely, A.; J. Chem. Soc. Dalton Trans. 1984, 4, 611.

10. Daniele, P. G.; Zerbinati, O.; Zelano, V.; Ostacoli, G.; J. Chem. Soc. Dalton Trans. 1991, 10, 2711.

11. Luiz, M. T. B.; Szpoganicz, B.; Rizzoto, M.; Martell, A. E.; Basallote, M. G.; Inorg. Chim. Acta 1997, 254, 345.
12. Várnagy, K.; Bóka, B.; Sóvágó, I.; Sanna, D.; Marras, P.; Micera, G.; Inorg. Chim. Acta 1998, 275, 440.

13. Nold, M. J.; Cerda, B. A.; Wesdeiotis, C.; J. Am. Soc. Mass Spectrom. 1999, 10, 1.

14. Harrison, A. G.; Csizmadia, I. G.; Tang, T.; J. Am. Soc. Mass Spectrom. 2000, 11, 427.

15. Bruni, S.; Cariati, F.; Daniele, P. G.; Prenestil, E.; Spectrochim. Acta, Part A 2000, 56, 815.

16. Szabó-Plánka, T.; Nagy, N.; Rockenbauer, A.; Korecz, L.; Polyhedron 2000, 19, 2049.

17. Szabó-Plánka, T.; Árkosi, Z.; Rockenbauer, A.; Korecz, L.; Polyhedron 2001, 20, 995.

18. Argirova, M. D.; Argirova, O. K.; Spectrochim. Acta, Part A 1999, 55, 245.

19. Garib, F.; Zare, K.; Habibi, M.; Tahghvamanesh, A.; Main Group Met. Chem. 2002, 25, 283.

20. Garib, F.; Zare, K.; Tahghvamanesh, A.; Shamel, A.; Shafiee, G.; Main Group Met. Chem. 2002, 25, 647.

21. Prenesti, E.; Daniele, P. G.; Toso, S.; Anal. Chim. Acta 2002, 459, 323.

22. Monajjemi, M.; Garib, F.; Aghaei, H.; Shafiee, G.; Thghvamanesh, A.; Shamel, A.; Main Group Met. Chem. 2003, $26,39$.

23. Lurie, Ju.; Handbook of Analytical Chemistry, $1^{\text {st }}$ ed., Mir: Moscow, 1975.

24. Gharib, F.; Nasiri, R.; Rev. Inorg. Chem. 2005, 25, 79.

25. Gharib, F.; Zare, K.; J. Sci., Isl. Azad Univ. 1992, 2, 397.

Received: December 5, 2006 Web Release Date: August 10, 2007 